\title{
Biochemical assessment of vitamin A in schoolchildren from a rural community
}

\author{
Ivete T. Graebner, ${ }^{1}$ Carlos H. Saito, ${ }^{2}$ Elizabeth M. T. de Souza ${ }^{3}$
}

\begin{abstract}
Objective: To investigate the prevalence of vitamin A deficiency among schoolchildren from a rural area in the Distrito Federal, Brazil, and to correlate this with rates of anemia and malnutrition.

Methods: From a total of 179 students, the study recruited 155 schoolchildren (5 to 18 years), whose parents gave permission for blood tests. Plasma retinol concentration was assayed by high resolution liquid chromatography, and levels of plasma vitamin A lower than $20 \mu \mathrm{g} / \mathrm{dL}$ were defined as abnormal or deficient in vitamin A. Hemoglobin was measured by an automated cell counter, and anemia was defined as serum concentrations of less than 11.5 and 12.0 $\mathrm{g} / \mathrm{dL}$ for children and adolescents, respectively. Nutritional status was assessed using z scores for weight/height, height/age and body mass index percentiles.
\end{abstract}

Results: The results indicated that $33.55 \%$ of the schoolchildren tested had a vitamin A deficiency, with a prevalence of $35.44 \%$ among children (5-9 years) and $31.58 \%$ among adolescents ( $10-18$ years). No correlation was observed between the prevalence of vitamin A deficiency and prevalence rates of anemia or malnutrition. Both sexes and all ages were homogeneous for vitamin A deficiency.

Conclusions: The elevated prevalence of vitamin A deficiency among the children and adolescents attending this rural school identify a public health problem in the region. These results indicate that age groups from 5 years onwards should be included in those at risk of hypovitaminosis $A$ and that they should be included in public policies aimed at combating hypovitaminosis $\mathrm{A}$.

J Pediatr (Rio J). 2007;83(3):247-252: Vitamin A, retinol, vitamin A deficiency, schoolchildren, hypovitaminosis A.

\section{Introduction}

Vitamin A is considered to be an essential micronutrient for epithelial differentiation and maintenance processes, and is well known because of the negative effects of deficiency. Research has demonstrated that, in addition to affecting the visual cycle, vitamin A deficiency is directly linked to reproduction, fetal development, the immune system and to regulation of cell proliferation and differentiation. ${ }^{1}$
The World Health Organization (WHO $)^{2}$ estimated that vitamin A deficiency was endemic in 39 countries, and Brazil was on their list.

Biochemical investigations carried out in our country have confirmed that vitamin A deficiency is a public health problem in the following states: São Paulo, Minas Gerais, Pernambuco, Ceará, Bahia, Amazonas and Rio de Janeiro. ${ }^{3,4}$ Isolated and scattered surveys of several different regions in Brazil

1. Doutoranda, Programa de Pós-Graduação em Ciências da Saúde, Universidade de Brasília, Brasília, DF, Brasil.

2. Doutor. Pesquisador, CNPq. Professor adjunto e Chefe, Departamento de Ecologia, Universidade de Brasília, Brasília, DF, Brasil.

3. Doutora. Pesquisadora, CNPq. Professora adjunta e Chefe, Departamento de Biologia Celular, Universidade de Brasília, Brasília, DF, Brasil.

Financial support: CNPq and CAPES (bursaries).

Manuscript received Sep 12 2006, accepted for publication Feb 282007.

Suggested citation: Graebner IT, Saito CH, de Souza EM. Biochemical assessment of vitamin A in schoolchildren from a rural community. J Pediatr (Rio J). 2007;83(3):247-252

doi $10.2223 / J P E D .1636$ 
suggest that 20 to $40 \%$ of the population suffer from subclinical or borderline deficiency, i.e. a low level of vitamin A in blood $(<20 \mu \mathrm{g} / \mathrm{dL}$ ) without symptomology, suggesting that these data may be linked to avoidance of foods rich in vitamin A. ${ }^{3}$ Although analysis of data from the last 20 years demonstrates that the deficiency is common in practically all of Brazil's geographic regions, no biochemical survey of vitamin A deficiency has been carried out in the Midwest Region. ${ }^{4}$

The objective of this study was to employ anthropometry and biochemical assessments, in the form of hemoglobin and plasma vitamin A assays, to investigate the nutritional status of schoolchildren attending a rural school located in Planaltina, a satellite-town of Brasília, DF, Brazil. The study was carried out in response to the school's administration's concerns over suspected nutritional deficiency among their students, which itself arose in response to an earlier project conducted by the same team, with the same rural community, on environmental education. ${ }^{5}$ The results could become the basis for the public policies needed to reduce the problems of nutritional deficiency, by means of nutritional education programs developed locally by the teachers of the public education system.

\section{Methods}

\section{Characteristics of the area and the school population}

This research was carried out during 2003, at the only public school- Escola Classe Osório Bacchin - in the Jardins do Morumbi rural settlement, in Planaltina, DF, which is located around $50 \mathrm{~km}$ from the city of Brasília. The school had 350 children enrolled in classes from infants to the eighth grade. The parents of 179 of these students gave their permission, in the form of a signed free and informed consent form, for participation in the nutritional survey and for blood to be taken, thereby comprising the study sample. Plasma vitamin A levels were assessed in 155 schoolchildren (5 to 18 years, first to eighth grades). These are the children of rural workers, the majority of whom are caretakers at country retreats. The schoolchildren's families were defined as low-income - around $90 \%$ of them earned less than twice the minimum wage - , and $65 \%$ received some type of assistance from the local government, such as milk, food aid, and others. ${ }^{6}$ The Research Ethics Committee at the Health Sciences Faculty of the Universidade de Brasília approved this research.

\section{Anthropometric assessment}

The children's nutritional status was assessed (age group 5 to 9 years) was assessed after calculating $z$ scores for weight/height and height/age using Epi-Info version 6.2, and based on the National Center for Health Statistics (NCHS) reference values. ${ }^{7}$ The definition of malnutrition employed a cutoff of -2.0 standard deviations, as recommended by the WHO. ${ }^{8}$ The nutritional status of the adolescents (10 to 14 years) was analyzed according to the distribution of body mass index $\left(B M I=\mathrm{kg} / \mathrm{m}^{2}\right)$ percentiles, by age and sex. ${ }^{8}$

\section{Analysis biochemical}

Anemia

Hemoglobin was assayed using an automated cell counter (COULTER T-890, Coulter Corporation), and anemia was diagnosed when hemoglobin concentration was below $11.5 \mathrm{~g} / \mathrm{dL}$ (age group 5 to 11 years) or $12.0 \mathrm{~g} / \mathrm{dL}$ (12 to 14 years), in accordance with the WHO. ${ }^{9}$

\section{Plasma vitamin A (retinol)}

The blood samples ( $5 \mathrm{~mL}$ in EDTA) were taken from the schoolchildren (5-18 years) after 12 hours' fasting at the school. Retinoid extraction was performed according to Ortega et al. ${ }^{10}$ with modifications. To $100 \mu \mathrm{L}$ of plasma were added $200 \mu \mathrm{L}$ of ethanol: methanol (1:1) containing $0.06 \%$ butylated hydroxytoluene and then hexane $(500 \mu \mathrm{L})$ was added. After two extractions, the supernatants were recombined, dried under nitrogen and the residue re-suspended in methanol $(200 \mu \mathrm{L})$. Quantification of the retinol was performed in duplicate by HPLC, with a Shim-park C18 column $(25 \mathrm{~cm})$ CLC-ODS and Shim-park CLC G-ODS guard column, with a mobile phase of methanol: water (95:5) at $1.0 \mathrm{~mL} / \mathrm{min}$ flow rate. The peak corresponding to vitamin $\mathrm{A}$ (retinol) at $325 \mathrm{~nm}$ (Shimadzu UV-VIS SPD-10AV) was identified and compared with the retention time of a standard retinol by Sigma-Aldrich. Blood was collected, handled and analyzed in low-light conditions. The plasma retinol levels were evaluated according to the classification published by the Interdepartmental Committee on Nutrition for National Defense (ICNND): ${ }^{11}$ high (> $50 \mu \mathrm{g} / \mathrm{dL}$ ), normal (20-50 $\mu \mathrm{g} / \mathrm{dL})$, low $(10-20 \mu \mathrm{g} / \mathrm{dL})$ and deficiency $(<10 \mu \mathrm{g} / \mathrm{dL})$. The WHO parameters ${ }^{12}$ for defining vitamin $A$ deficiency as a public health problem were adopted. Therefore, when $5 \%$ of the population exhibit vitamin A levels $<10 \mu \mathrm{g} / \mathrm{dL}$ or $20 \%$ of the population exhibit $<20 \mu \mathrm{g} / \mathrm{dL}$, than vitamin A deficiency can be considered a public health problem.

\section{Statistical analysis}

The study population is described statistically in the form of frequencies of each group within each category of interest. Age categories (child or adolescent) and sexes were compared in terms of the results of vitamin A and hemoglobin concentrations and of anthropometric measurements using ANOVA (factorial $2 \times 2$ ). All data were analyzed using the statistical software Statistica 5.0.

\section{Results}

Consent was obtained for $51 \%$ of the children enrolled at the school to take part in the study (179 out of 350 ), limiting 
extrapolation of the results to all of the schoolchildren because of an absence of previous data that could allow the sample to be compared with the population.

The results on plasma vitamin A levels are for 155 schoolchildren (aged 5 to 18 years), since 24 children (13\%) did not have blood samples taken, either because they were absent from school or because they refused to give blood, despite their parent or guardian insisting. This is the study's true loss.

Of the 155 schoolchildren studied, $60 \%$ were male, $47 \%$ were children (5-9 years) and 53\% adolescents (10-18 years), which data are similar to those for the children who did not take part $(n=171)$, where $60 \%$ were also male and $62 \%$ were adolescents.

With relation to socioeconomic data on the schoolchildren assessed, a parallel study conducted by Rivera \& Souza ${ }^{6}$ found that $73 \%$ lived in homes with four to six residents and $41 \%$ of mothers had a low educational level. The monthly earnings of $87.4 \%$ of heads of families was less than two minimum monthly wages and, the heads of $35 \%$ of families were female. Table 1 contains an evaluation of the plasma vitamin A levels, and it can be observed that approximately $34 \%$ of the total number of schoolchildren assessed ( 52 out of 155 ) had deficient levels ( $<20 \mu \mathrm{g} / \mathrm{dL}$ ). Mean plasma vitamin A concentration varied from 22 to $25 \mu \mathrm{g} / \mathrm{dL}$ (Table 2). Comparison of the vitamin A levels of children ( 5 to 9 years) with those of adolescents (10 years) detected no difference between vitamin A concentration in the blood ( $F=1.51$ and $\mathrm{p}=0.0983)$, neither did the comparison between sexes $(F=1.78$ and $p=0.204)$.

Table 3 contains the frequencies of the two vitamin A levels in relation to malnutrition and anemia, by age group (children and adolescents). One of the children analyzed $(1.4 \%)$ was underweight $(\mathrm{W} / \mathrm{H})$, although chronic malnutrition $(\mathrm{H} / \mathrm{A})$ was present in four children $(5.5 \%)$, and these children also exhibited vitamin A deficiency. Among the adolescents, $7.5 \%$ were underweight (BMI), and just one had deficient vitamin A levels. Moreover, the prevalence of malnutrition chronic was $6 \%$ among the adolescents, $3 \%$ of whom had vitamin A deficiency. Low hemoglobin levels were detected in the blood of $8 \%$ of the total number of schoolchildren tested, and vitamin A deficiency was detected in $5.5 \%$ of the population of children and $1.5 \%$ of the adolescents.

\section{Discussion}

In Brazil, surveys of hypovitaminosis A in rural areas are rare, and studies that use biochemical criteria to diagnose deficiency are scarcer still. One of the few reports on vitamin A deficiency in rural areas was published by Prado et al. ${ }^{13}$ and describes a $44.7 \%$ prevalence rate of vitamin A deficiency among preschool children in the state of Bahia. That prevalence is greater than was observed among preschool

Table 1 - Prevalence of plasma vitamin A levels for children and adolescents of both sexes

\begin{tabular}{|c|c|c|c|c|c|}
\hline \multirow[b]{3}{*}{$\begin{array}{l}\text { Plasma vitamin A } \\
\text { levels }(\mu \mathrm{g} / \mathrm{dL}) *\end{array}$} & \multicolumn{4}{|c|}{ Age group $(n=155)$} & \multirow[b]{3}{*}{ Total } \\
\hline & \multicolumn{2}{|c|}{$5-9$ years $^{+}$} & \multicolumn{2}{|c|}{$\geq 10$ years $^{+}$} & \\
\hline & Male & Female & Male & Female & \\
\hline \multicolumn{6}{|l|}{ Sufficient $>20$} \\
\hline $\mathrm{n}$ & 31 & 20 & 32 & 20 & 103 \\
\hline$\%$ & 39.24 & 25.31 & 42.10 & 26.31 & 66.46 \\
\hline \multicolumn{6}{|l|}{ Deficient $<20$} \\
\hline $\mathrm{n}$ & 14 & 14 & 15 & 9 & 52 \\
\hline$\%$ & 17.72 & 17.72 & 19.74 & 11.84 & 33.54 \\
\hline
\end{tabular}

* According to ICNND ${ }^{11}$ classification.

${ }^{+}$Analysis of variance with $\mathrm{F}$ test, $\mathrm{F}=1.38, \mathrm{p}=0.124$. 
children in a semi-arid urban area of Bahia (31.9\%), ${ }^{14}$ which could indicate a need for greater attention to rural areas of the country.

In this study we observed that around $1 / 3$ of the schoolchildren assessed exhibited abnormally low vitamin A levels (less than $20 \mu \mathrm{g} / \mathrm{dL}$ ). Our data are similar to the results of research carried out in several Brazilian regions, ${ }^{3,4}$ which describe vitamin A deficiency as a public health problem in those locations. Geraldo et al. ${ }^{3}$ suggested the possibility that vitamin A deficiencies existed also existed among school aged children. Considering that the school in question here is the only school in the Jardim do Morumbi rural settlement, in Planaltina, DF, our result should serve as a warning to public

Table 2 - Means with minimum and maximum values of plasma vitamin A levels by age group and sex

\begin{tabular}{|c|c|c|c|c|c|c|c|c|}
\hline \multirow[b]{3}{*}{ Sex } & \multicolumn{8}{|c|}{ Plasma vitamin A levels ( $\mu \mathrm{g} / \mathrm{dL}$ ) } \\
\hline & \multicolumn{4}{|c|}{$5-9$ years } & \multicolumn{4}{|c|}{$\geq 10$ years } \\
\hline & Mean* & \pm SD & Min & Max & Mean & \pm SD & Min & Max \\
\hline Female & $21.94^{a}$ & 7.55 & 8.00 & 43.79 & $24.85^{a}$ & 8.20 & 10.79 & 42.15 \\
\hline Male & $24.61^{a}$ & 7.59 & 9.95 & 44.55 & $24.87^{a}$ & 9.25 & 11.35 & 66.17 \\
\hline
\end{tabular}

$\mathrm{SD}=$ standard deviation

$*$ Means that are followed by the same letter do not differ according to ANOVA, F test, $\mathrm{p}=0.124$

Table 3 - Nutritional status and sufficiency of plasma vitamin A levels by age group

\begin{tabular}{|c|c|c|c|c|c|c|c|c|}
\hline \multirow[b]{4}{*}{ Nutritional status* } & \multicolumn{8}{|c|}{ Plasma vitamin A levels $(\mu \mathrm{g} / \mathrm{dL})$} \\
\hline & \multicolumn{4}{|c|}{ Children $(n=73)$} & \multicolumn{4}{|c|}{ Adolescents $(n=67)$} \\
\hline & \multicolumn{2}{|c|}{ Sufficient } & \multicolumn{2}{|c|}{ Deficient } & \multicolumn{2}{|c|}{ Sufficient } & \multicolumn{2}{|c|}{ Deficient } \\
\hline & $\mathbf{n}$ & $\%$ & $\mathbf{n}$ & $\%$ & $\mathbf{n}$ & $\%$ & $\mathbf{n}$ & $\%$ \\
\hline Well-nourished $(z \geq-2)$, W/H & 48 & 65.75 & 24 & 32.88 & 39 & 58.21 & 23 & 34.33 \\
\hline Malnourished $(z<-2)$, W/H & 1 & 1.37 & 0 & 0 & 4 & 5.97 & 1 & 1.49 \\
\hline Well-nourished $(z \geq-2), H / A$ & 69 & 94.52 & 0 & 0 & 41 & 61.19 & 22 & 32.83 \\
\hline Malnourished $(z<-2), H / A$ & 0 & 0 & 4 & 5.47 & 2 & 2.99 & 2 & 2.99 \\
\hline Normal & 46 & 63.01 & 19 & 26.03 & 40 & 59.70 & 24 & 35.83 \\
\hline Anemic & 4 & 5.48 & 4 & 5.48 & 2 & 2.98 & 1 & 1.49 \\
\hline
\end{tabular}


organs with relation to this deficiency. According to the WHO, ${ }^{12}$ the results classify vitamin A deficiency as being a public health problem in this community and it should be included in programs aimed at combating deficiencies.

Taking account of studies that employed biochemical diagnosis, vitamin A deficiency has been shown to be a public health problem in the Southeast Region(São Paulo, Minas Gerais and Rio de Janeiro), the Northeast Region (Pernambuco, Ceará, Bahia) and in the North Region (Amazonas). ${ }^{3}$ However, Ramalho et al. ${ }^{15}$ appear to have indicate a lessening of this deficiency in certain urban areas, such as in Rio de Janeiro, where low serum vitamin A levels were observed in $11.98 \%$ of the age group from 7 to 10 years and in $7.92 \%$ of adolescents ( 10 to 17 years). However, in the Midwest Region there have been no surveys undertaken, whether using biochemical analysis or dietary recall, of vitamin A deficiency associated with anemia and malnutrition in urban or rural schoolchildren.

We emphasize that the results presented in our study are the first biochemical assessment of plasma vitamin A levels in rural schoolchildren from the Distrito Federal, Brazil. The high observed prevalence appears to indicate the continuation of a tendency observed in the 1980 s by Dorea et al., ${ }^{16}$ when $12 \%$ of children exhibited inadequate hepatic retinol reserves ( $\leq 20 \mu \mathrm{g} / \mathrm{g}$ of liver).

Although vitamin A deficiency is common among populations of low socioeconomic status, in this study it appears not only to be associated with low levels of consumption of foods containing vitamin A, but also with lack of information on healthy nutrition. In deed, the children live in a rural area of the Distrito Federal where they have access to foods native to the Cerrado, such as the pequi fruit (Caryocar brasiliense), ${ }^{17}$ or dark-green vegetables, such as caruru (Amaranthus viridis), taioba (Xanthossoma sagittifolium) and serralha (Sonchus oleraceus), which have been proven to be sources of bioavailable pro-vitamin A carotenoids. ${ }^{18}$ The dietary survey undertaken in this community, did indeed indicate low levels of fruit and vegetable consumption. ${ }^{19}$ In these circumstances, prevention by means of supplementation with vitamin $A^{20}$ could reduce the rates of this deficiency over the short term, while guidance on choosing a healthy diet, including sources of carotenoids and vitamin $A$, could bring results over the medium and long term. Working together to improve awareness of the issue, the teachers of infant and primary schools can play an important role promoting a wide-ranging, informative and explanatory campaign to achieve safe and healthy nutrition.

There are published data that suggest the existence of a positive relationship between vitamin A deficiency and malnutrition, but in our analysis it was not possible to detect a relation between plasma vitamin A levels and inadequate nutritional status, probably because of the low prevalence of malnutrition in this population. ${ }^{19}$ The same authors also assessed hemoglobin and ferritin levels. Evaluation of that result compared with the vitamin A levels observed in the present study did not demonstrate a relation between prevalence rates. A similar result was observed by Ferraz et al., ${ }^{20}$ who found a high prevalence of vitamin A deficiency in a population of preschool children with a low occurrence of malnourishment.

Despite the efforts of governmental policies to combat micronutrient deficiencies, ${ }^{21}$ investigations continue to detect high prevalence rates, both in remote areas that are known to be pockets of poverty and also in regions of economic prosperity. We have already mentioned that, despite the fact that the Midwest Region is not included in the country's social programs aimed at reducing dietary deficiencies, these deficiencies do seem to exist among the populations of small communities. The below normal plasma vitamin A levels found among the schoolchildren of the rural community of Planaltina, DF, indicate that the distribution $n$ of this deficiency is not limited to urban regions and that adolescents should be added to the list of groups at risk of vitamin A deficiency and, therefore, added to the Program to Combat Hypovitaminosis A. ${ }^{21}$

\section{Acknowledgements}

To the administration and teaching staff at the Escola Classe Osório Bacchin, in particular to the teachers Rosária Rosa dos Santos Ramos and Vera Lúcia Santos de Oliveira, for their help with compiling student registration data.

\section{References}

1. Biswas AB, Mitra NK, Chakraborty I, Basu S, KumarS. Evaluation of vitamin A status during pregnancy. J Indian Med Assoc. 2000;98:525-9.

2. World Health Organization. Global prevalence of vitamin A deficiency: micronutrient deficiency information system. Geneva: WHO; 1995. Working Paper No. 2. Document WHO/ NUT/95.3.

3. Ramalho RA, Flores $\mathrm{H}$, Saunders C. Hipovitaminose A no Brasil: um problema de saúde pública. Rev Panam Salud Publica. 2002; 12:117-22.

4. Geraldo RRC, Paiva SAR, Pitas AMCS, Godoy I, Campana AO. Distribuição da hipovitaminose $A$ no Brasil nas últimas quatro décadas: ingestão alimentar, sinais clínicos e dados bioquímicos. Rev Nutr. 2003;16:443-60.

5. Saito CH, Franco EM, Vasconcelos IP, Graebner IT, Dusi RLM. Educação ambiental na cachoeira do Morumbi. Brasília: Dupligráfica; 2001.

6. Rivera FSR, Souza EMT. Perfil nutricional e socioeconômico de escolares de uma comunidade rural. Rev Saude do Distrito Federal. 2005;16:23-31. 
7. National Center for Health Statistics, Center for Disease Control and Prevention. Growth charts 2002. http://www.cdc.gov. Access: $15 / 10 / 2003$.

8. World Health Organization. Physical status: the use and interpretation of anthropometry. Geneva: WHO; 1995. WHO Technical Report Series, 854.

9. World Health Organization. Iron deficiency anaemia: assessment, prevention and control. A guide for programme managers. Geneva: WHO; 2001. Document WHO/NHD/01.3.

10. Ortega H, Coperías JL, Castilla P, Gómez-Coronado D, Lasunción A. Liquid chromatographic method for the simultaneous determination of different lipid-soluble antioxidants in human plasma and low-density lipoproteins. J Chromatogr B Analyt Technol Biomed Life Sci. 2004;803:249-55.

11. Interdepartamental Committee on Nutrition for National Defense. Manual for nutrition survey. Washington: Government Printing Office; 1983.

12. World Health Organization. Indicators for assessing vitamin A deficiency application in monitoring and evaluating intervention programmes. Geneva: WHO; 1996. Document WHO/NUT/ 96.10

13. Prado MS, Assis AMO, Martins MC, Nazaré MPA, Rezende IFB, Conceição MEP. Hipovitaminose $A$ em crianças de áreas rurais do semi-árido baiano. Rev Saude Publica. 1995;29:295-300.

14. Santos LMP, Assis AMO, Martins MC, Araújo MPN, Amorim DQ, Morris SS, et al. Situação nutricional e alimentar de préescolares no semi-árido da Bahia. II - Hipovitaminose A. Rev Saude Publica. 1996;30:67-74.
15. Ramalho RA, Saunders C, Natalizi DA, Cardoso LO, Accioly E. Níveis séricos de retinol em escolares de 7 a 17 anos no município do Rio de Janeiro. Rev Nutr. 2004;17:461-8.

16. Dorea JG, Souza JA, Galvao MO, Iunes MA. Concentration of vitamin $A$ in the liver of foetuses and infants dying of various causes in Brasilia, Brazil. Int J Vitam Nutr Res. 1984;54:119-23.

17. Silva DB da, Silva JA da, Junqueira NTV, Andrade LRM. Frutas do cerrado. Planaltina: Embrapa Cerrados. Brasília: Embrapa Informação Tecnológica; 2001.

18. Graebner IT, Siqueira EMA, Arruda SF, Souza EMT. Carotenoids from native Brazilian dark-green vegetables are bioavailable: a study in rats. Nutr Research. 2004;24:671-9.

19. Rivera FSR, Souza EMT. Consumo alimentar de escolares de uma comunidade rural. Comum Cienc Saude. 2006;17:111-9.

20. Ferraz IS, Daneluzzi JC, Vannucchi H, Jordão Jr. AA, Ricco RG, Del Ciampo LA, et al. Prevalência da carência de ferro e sua associação com a deficiência de vitamina A em pré-escolares. J Pediatr (Rio J). 2005;81:169-74.

21. Brasil, Ministério da Saúde. Programa Nacional de Suplementação de Vitamina A. http://dtr2004.saude.gov.br/ nutricao/mn/vita/index.php. Access: 28/03/2006.

Correspondence:

Ivete Teresinha Graebner

Condomínio Ouro Vermelho II, QD 16, casa 2, Lago Sul

CEP 71680-385 - Brasília, DF - Brazil

Tel.: +55 (61) 3307.2326

Fax: +55 (61) 3273.4579

E-mail: ivete.graebner@gmail.com 